\title{
THE EFFECT OF DIET SUPPLEMENTATION WITH PROPOLIS ON IMMUNOLOGICAL AND PHYSICOCHEMICAL PROPERTIES OF TIBIA BONES IN BROILER CHICKENS
}

\author{
A.E.Abou-Zeid ${ }^{1}$; S.Z. El-Damarawy ${ }^{1}$; Y.A. Mariey ${ }^{2}$ and S.M. El-Kasass ${ }^{1}$ \\ ${ }^{1}$ Animal Production Department, Faculty of Agriculture, Tanta University, Egypt. \\ ${ }^{2}$ Animal Production Research Center, Egypt.
}

SUMMARY

\begin{abstract}
A trial was carried out to determine the effects of diet supplementation with propolis on immunological status and bone physicochemical properties of broiler at 6 weeks of age. Two hundred and forty one-day-old unsexed Cobb broilers chicks were randomly distributed into four equal experimental groups; with three replicates of 20 chicks each. They were fed on one of the following propolis levels; $0,125,250$ and $500 \mathrm{mg} / \mathrm{kg}$ diet. The tibia length, percentage relative to live body weight, dry matter, ash of tibia bone, phosphorus and calcium concentrations were determined at the end of the experiment. The results showed that, propolis supplementation at 125,250 and $500 \mathrm{mg} / \mathrm{kg}$ diet increased $(\mathrm{p}<0.05)$ the tibia length by $3,2.4$ and $3.4 \%$, respectively, when compared to the control group. The higher value of tibia percentage relative to live body weight was recorded in the group fed propolis supplementation at $125 \mathrm{mg} / \mathrm{kg}$ diet, followed by groups fed $250,500 \mathrm{mg}$ propolis $/ \mathrm{kg}$ diet and group that fed control diet. Propolis supplementation at 125,250 and $500 \mathrm{mg} / \mathrm{kg}$ increased phosphorus concentrations by $4.6,1.1$ and 1.8 $\%$, respectively. Also, calcium concentrations in ash were increased by $0.6,2.9$ and $3.1 \%$, respectively, when compared to the control group. Although, all groups had haemagglutination inhibiting antibodies against NDV, the highest haemagglutination inhibiting antibody titer was obtained from birds fed diets supplemented with 125 and $250 \mathrm{mg}$ propolis/ $\mathrm{kg}$ diet at 35 days of age. In addition, data showed that the concentration of $500 \mathrm{mg}$ propolis/kg diet did not significantly influence the humoral immune response of broiler against NDV.
\end{abstract}

Keywords: Broilers, propolis, $\mathrm{Ca}, \mathrm{P}$ and immune response.

\section{INTRODUCON}

Broiler chickens are characterized by a very fast growth rate; therefore broiler diets should contain high concentrations of available nutrients (Zimnoch et al., 2000). The adverse effect of broiler selection programs that focus on increasing growth rate and improve the immune-response against diseases, a higher incidence of leg problems, in particular bone deformities and abnormalities (Leterrier and Nys 1992, Horn 2000, Williams et al., 2004).

Recently, natural materials have been investigated in order to prove its effectiveness as a growth promoter such as Propolis. It is a resinous substance collected by worker bees (Apis mellifera) from the bark of trees and leaves of plants (Nada et al., 2011).

Propolis plays an important role in the elimination of acute and chronic pain and mortality resulting from osteoporotic fractures which pose serious animal welfare concerns (Danbury et al., 2000) and increase economic loss (Cook, 2000) by increased mortality resulting from skeletal diseases (Sullivan, 1994; Thorp, 1994).

Furthermore, several researchers (Sforcin, 2007; Galal et al., 2008; Attia et al., 2011b,c; PopielaPleban et al., 2012) demonstrated that Propolis could be used as growth promoters and immune enhancers as an alternative to antibiotics. In addition, Propolis has been suggested as a suitable health supplement for consumers in developed countries (Bankova, 2005).Also, the oxidative stress that can be caused by environmental factors, disease, infection, inflammation, aging, reactive oxygen species (ROS) production include free radicals and other oxygenated molecules resulting from these factors may be minimized by antioxidant defense mechanisms that protect the cell against cellular oxidants and repair systems that prevent the accumulation of oxidative damaged molecules on 14, 21 and 28 days respectively. 
Ihsan et al. (2013) reported that, propolis has a positive role against Newcastle disease virus when they studied the effect of propolis in diet supplementation on the histopathological changes in some organs and challenge tests against Newcastle disease in broiler chicks.

Therefore, the aim of this study is to investigate the effect of propolis supplementation in broiler diets on immunological and bone physiological status.

\section{MATERIALS AND METHODS}

This study was carried out at two parts; the first one was the extraction procedure of the propolis alcoholic extract in the laboratory using ethanol alcohol 96\%, the second was a field study carried out at a private commercial farm under supervision of Animal Production Department, Faculty of Agriculture, Tanta University, during the period from October to December 2014 to investigate the effect of feeding diets with 0, 125, 250, $500 \mathrm{mg}$ Ethanolic Extracts of Propolis/kg diet on broiler physiological and immunological status.

\section{Preparation of ethanolic extracts of propolis (EEP):}

Propolis samples were purchased from Elzahaby phytopharm,in powder form. 35gm of propolis powder were mixed with $70 \mathrm{ml}$ of $96 \%$ ethanol alcohol and left for 14 days, in a dark cool place (not in refrigerator) and was shaken also 3 times per day. After two weeks the solution was filtered; the liquid portion was stored in a dark green bottle in a cool, dry and dark place. The ethanolic extract solution was then filtered through a Whattman No.1 filter paper and restored to the original volume with $96 \%$ ethanol (Khojasteh and Shivazad 2006), then different concentrations of EEP were prepared at a rate of 125, 250 and $500 \mathrm{mg}$ and stored in a dark green bottle in a cool, dry and dark place.

\section{Experimental design:}

Two hundred and forty one-day-old unsexed Cobb broilers chicks were used in this experiment, randomly distributed into four equal experimental groups; with three replicates of 20 chicks each. The average initial body weights of the treatments groups were nearly similar with no observed significant differences. Chicks were grown in floor pens and subjected to $23 \mathrm{hrs}$. lighting along the experimental period which extended to 6 weeks of age. The house temperature was kept at about $34^{\circ} \mathrm{C}$ during the first 3 days, $32^{\circ} \mathrm{C}$ during next 4 days and thereafter, gradually decreased by $3{ }^{\circ} \mathrm{C}$ weekly down to $24^{\circ} \mathrm{C}$. Pellets feed form and water were available ad libitum throughout the experimental period. All experimental groups were reared under similar managerial and hygienic conditions.

\section{Experimental Diets:}

The basal diet was a commercial corn-soybean meal diet formulated to meet or exceed the nutritional requirement of growing chicks as recommended by NRC (1994) as shown in Table 1.

\section{Dietary treatments evaluated included:}

Control (Basal diet without any addition), T2 (Basal diet supplemented with $125 \mathrm{mg} / \mathrm{kg}$ EEP), T3 (Basal diet supplemented with $250 \mathrm{mg} / \mathrm{kg}$ EEP) and T4 (Basal diet supplemented with $500 \mathrm{mg} / \mathrm{kg} \mathrm{EEP}$ ).

\section{Measurements:}

Tibia bones were separated, removing cartilage. Their weight and length of the tibia were determined. The measurements were taken with an electronic caliper, based on the geometric characteristics of the tibia.

The content of crude ash and minerals (calcium and phosphorus) in tibia bones was determined after dry mineralization at $650{ }^{\circ} \mathrm{C}$. Ca content was measured by spectrophotometer, and $\mathrm{P}$ content was estimated calorimetrically. Bone samples were mineralized in a mixture of nitric acid and perchloric acid (3:1). Mineralization was carried out in an aluminum heating block with temperature control. Reference samples were prepared together with test samples. The $\mathrm{Ca}$ content of mineralizates was determined by flame atomic absorption spectrometry (acetylene-air flame), with the use of Unicom 939 atomic absorption spectrometer, equipped with an Optimus data station, a background correction source (deuterium lamp) and cathode lamps (Whiteside and Miner 1984). In order to determine Ca content, a 10 $\%$ aqueous solution of lanthanum chloride was added to all experimental solutions, in the amount ensuring the final La+3 concentration of $1 \%$. Phosphorus concentration was determined in mineralizates by colorimeter with ammonium molybdate and with sodium sulfate and hydroquinone. Absorbance was 
measured using a VIS 6000 spectrophotometer (A. KRÜSS Optronic GmbH, Hamburg, Germany), at a wavelength of $\lambda=610 \mathrm{~nm}$ (Fiske and Subbarow1925). The content of $\mathrm{Ca}$ and $\mathrm{P}$ was determined using standards at a concentration of $1 \mathrm{mg} / \mathrm{cm} 3$, diluted with a $0.1 \mathrm{M}$ solution of HNO3 (Kleczeket et al., 2012).

\section{Haemagglutination Inhibition (HI) Test:}

After 10 days of Lasota vaccination, blood samples were collected. Blood serum was separated by centrifugation at $3000 \mathrm{rpm}$ for $20 \mathrm{~min}$. The collected serum was kept frozen at $-20^{\circ} \mathrm{C}$ until assay. The beta-procedure of the HI test was employed as a micro-test in plastic plates as outlined in "Methods for Examining Poultry Biologics and for Identifying and Quantifying Avian Pathology" (Anon, 1990).

Table (1). The composition and calculated analysis of experimental starter, grower and finisher diets.

\begin{tabular}{|c|c|c|c|}
\hline \multirow[t]{2}{*}{ Ingredients } & \multicolumn{3}{|c|}{ Experimental diets } \\
\hline & Starter & Grower & Finisher \\
\hline Yellow corn & 54 & 61 & 63.5 \\
\hline Soybean meal (44\%) & 29 & 26.5 & 24 \\
\hline Wheat brain & 2.3 & 0.8 & - \\
\hline Corn gluten meal (62\%) & 8.5 & 4.8 & 4.8 \\
\hline Soybean oil & 2.5 & 3.2 & 4 \\
\hline Dl-Methionine & 0.1 & 0.1 & 0.1 \\
\hline L. Lysine & 0.1 & 0.1 & 0.1 \\
\hline Limestone & 1.4 & 1.4 & 1.4 \\
\hline Dicalcium phosphate & 1.5 & 1.5 & 1.5 \\
\hline Salt & 0.3 & 0.3 & 0.3 \\
\hline Premix $^{* *}$ & 0.3 & 0.3 & 0.3 \\
\hline Total & 100.00 & 100.00 & 100.00 \\
\hline \multicolumn{4}{|l|}{ Calculated analysis } \\
\hline Crude protein $(\%)$ & 23.01 & 20.05 & 19.03 \\
\hline $\mathrm{ME}(\mathrm{Kcal} / \mathrm{Kg})$ & 3025 & 3109 & 3196 \\
\hline Ether extract $(\%)$ & 3.40 & 3.8 & 4.0 \\
\hline Crude fiber $(\%)$ & 3.50 & 3.60 & 3.20 \\
\hline Calcium $(\%)$ & 0.95 & 0.94 & 0.94 \\
\hline Available phosphorus (\%) & 0.41 & 0.40 & 0.39 \\
\hline Methionine $(\%)$ & 0.5 & 0.43 & 0.44 \\
\hline Lysine $(\%)$ & 1.1 & 1.00 & 0.93 \\
\hline Mt cysteine & 0.94 & 0.90 & 0.88 \\
\hline \multicolumn{4}{|c|}{ 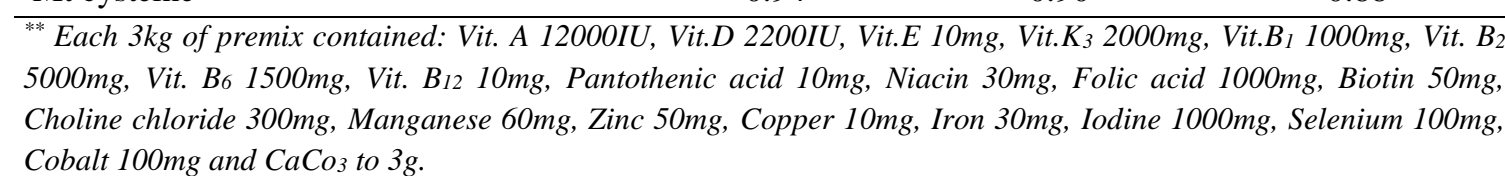 } \\
\hline
\end{tabular}

\section{Statistical analysis:}

Data were statistically analyzed by one-way ANOVA, using the general linear model procedure (SAS, 1996). Tests of significance for differences among treatments were done according to Duncan (1955). The statistical model was used for the analysis of variance to estimate the effect of dietary propolis supplementation as follows:

$\mathrm{Y}_{\mathrm{ijk}}=\mathrm{U}+\mathrm{T}_{\mathrm{i}}+\mathrm{R}_{\mathrm{j}}+\mathrm{e}_{\mathrm{ijk}}$

Where, $Y_{i j k}$ is the observations; $U$ is overall mean; $T_{i}$ is effect of $i$ treatment ( $i=0,1,2$ and 3); $R_{j}$ is effect of $\mathrm{j}$ replicate $\left(\mathrm{j}=1,2\right.$ and 3 ) and $\mathrm{e}_{\mathrm{ijk}}$ is residual (random error).

\section{RESULTS AND DISCUSSION}

\section{Bone physiological status:}

Table (2) shows the effect of propolis supplementation on tibia weight, length and tibia percentage of live body weight. It is obvious that, propolis supplementation increased significantly $(\mathrm{p}<0.01)$ tibia 


\section{Abou-Zeid et al.}

weights. The highest value of tibia weights was in the group fed propolis supplementation at $125 \mathrm{mg} / \mathrm{kg}$ diet. While, the least tibia weights were in the group fed control diet.

Propolis supplementation at 125,250 and $500 \mathrm{mg} / \mathrm{kg}$ diet increased significantly $(\mathrm{p}<0.05)$ the tibia length by 3,2.4 and $3.4 \%$ respectively, when compared to the control group.

The highest value of tibia percentage relative to live body weight was recorded in the group fed propolis supplementation at $125 \mathrm{mg} / \mathrm{kg}$ diet, followed by groups fed 250, $500 \mathrm{mg}$ propolis/ $\mathrm{kg}$ diet and group that fed control diet.

Table (2). Effect of dietary propolis supplementation on physical properties (Mean \pm SE) of the tibia bone.

\begin{tabular}{|c|c|c|c|c|c|}
\hline Treatments & Control(T1) & $125(\mathrm{~T} 2)$ & $250(\mathrm{~T} 3)$ & $500(\mathrm{~T} 4)$ & Sign, \\
\hline \multicolumn{6}{|l|}{ Traits } \\
\hline Tibia weight $g$ & $\begin{array}{l}20.07 \pm 0.75^{b} \\
\quad(100 \%)\end{array}$ & $\begin{array}{l}23.47 \pm 0.58^{\mathrm{a}} \\
\quad(116.9 \%)\end{array}$ & $\begin{array}{c}21.86 \pm 0.76^{\mathrm{ab}} \\
(108.91 \%)\end{array}$ & $\begin{array}{l}22.16 \pm 0.52^{\mathrm{a}} \\
(110.4 \%)\end{array}$ & $* *$ \\
\hline Tibia length mm & $\begin{array}{l}92.63 \pm 0.98^{b} \\
(100 \%)\end{array}$ & $\begin{array}{c}95.37 \pm 0.59^{\mathrm{a}} \\
(102.95 \%)\end{array}$ & $\begin{array}{c}94.83 \pm 0.46^{\mathrm{a}} \\
(102.37 \%)\end{array}$ & $\begin{array}{c}95.77 \pm 0.75^{\mathrm{a}} \\
(103.38 \%)\end{array}$ & $*$ \\
\hline $\begin{array}{l}\text { Tibia percentage in the total } \\
\text { body weight } \%\end{array}$ & $\begin{array}{c}1.02 \pm 0.003^{\mathrm{b}} \\
(100 \%)\end{array}$ & $\begin{array}{c}1.05 \pm 0.009^{\mathrm{a}} \\
(102.94 \%)\end{array}$ & $\begin{array}{c}1.04 \pm 0.009^{\mathrm{ab}} \\
(101.96 \%)\end{array}$ & $\begin{array}{c}1.04 \pm 0.007^{\mathrm{ab}} \\
(101.96 \%)\end{array}$ & $*$ \\
\hline $\begin{array}{l}\text {-Means of each column followe } \\
\text { Duncan's Multiple Range Test. } \\
\text {-* indicate } P<0.05\end{array}$ & $y$ the same le & are not signif & ntly different $a$ & & \\
\hline
\end{tabular}

\section{Bone chemical properties:}

Table (3) shows the effect of propolis supplementation on mineral composition of the tibia bone. The dry matter and Ash of tibia bone for broiler groups were not statistically affected by propolis containing diets, when compared to control group. The highest content of dry matter and ash were noted in the tibia bones of broilers fed a diet supplemented with propolis at $250 \mathrm{mg} / \mathrm{kg}$. followed by $500 \mathrm{mg} / \mathrm{kg} \mathrm{diet;} 250$ $\mathrm{mg} / \mathrm{kg}$ diet and the control respectively.

Phosphorus and calcium concentrations in ash were highest in the tibia bones of broilers fed supplemented diet with propolis when, compared to the control group. Propolis supplementation at 125 , 250 and $500 \mathrm{mg} / \mathrm{kg}$ increased Phosphorus concentrations by 4.6, 1.1 and $1.8 \%$ respectively, when compared to the control group. Also, calcium concentrations in ash were increased by $0.6,2.9$ and $3.1 \%$ respectively, when compared to the control group.

Table (3). Effect of dietary propolis supplementation on minerals composition (Mean \pm SE) of the tibia bone.

\begin{tabular}{|c|c|c|c|c|c|}
\hline Treatments & Control(T1) & $125(\mathrm{~T} 2)$ & $250(\mathrm{~T} 3)$ & $500(\mathrm{~T} 4)$ & Sign, \\
\hline \multicolumn{6}{|l|}{ Traits } \\
\hline Tibia dry matter \% (1mg/cm3) & $\begin{array}{l}96.75 \pm 0.16 \\
(100 \%)\end{array}$ & $\begin{array}{c}96.67 \pm 0.21 \\
(99.91 \%)\end{array}$ & $\begin{array}{l}97.02 \pm 0.05 \\
(100.28 \%)\end{array}$ & $\begin{array}{c}97.00 \pm 0.08 \\
(100.26 \%)\end{array}$ & NS \\
\hline $\begin{array}{l}\text { Ash in tibia dry matter\% } \\
(1 \mathrm{mg} / \mathrm{cm} 3)\end{array}$ & $\begin{array}{c}55.72 \pm 0.42 \\
(100 \%)\end{array}$ & $\begin{array}{c}55.78 \pm 0.4 \\
(100.1 \%)\end{array}$ & $\begin{array}{l}56.57 \pm 0.2 \\
(101.52 \%)\end{array}$ & $\begin{array}{c}55.88 \pm 0.37 \\
(100.29 \%)\end{array}$ & NS \\
\hline $\begin{array}{l}\text { Phosphorus in ash \% } \\
(1 \mathrm{mg} / \mathrm{cm} 3)\end{array}$ & $\begin{array}{l}17.58 \pm 0.23^{b} \\
(100 \%)\end{array}$ & $\begin{array}{c}18.38 \pm 0.25^{\mathrm{a}} \\
(104.55 \%)\end{array}$ & $\begin{array}{c}17.78 \pm 0.31^{\mathrm{ab}} \\
(101.14 \%)\end{array}$ & $\begin{array}{l}17.9 \pm 0.1^{\mathrm{ab}} \\
(101.82 \%)\end{array}$ & $*$ \\
\hline Calcium in ash $\%(1 \mathrm{mg} / \mathrm{cm} 3)$ & $\begin{array}{c}40.23 \pm 0.22^{\mathrm{b}} \\
\quad(100 \%)\end{array}$ & $\begin{array}{c}40.47 \pm 0.15^{\mathrm{b}} \\
(100.60 \%)\end{array}$ & $\begin{array}{l}41.4 \pm 0.17^{\mathrm{a}} \\
(102.90 \%)\end{array}$ & $\begin{array}{c}41.47 \pm 0.19^{\mathrm{a}} \\
(103.08 \%)\end{array}$ & $* * *$ \\
\hline $\begin{array}{l}\text {-Means of each column followed } \\
\text { Duncan's Multiple Range Test. }\end{array}$ & $v$ the same lett & are not signifi & tly different at & e $5 \%$ level acc & ding \\
\hline
\end{tabular}


Similar results were found by Haro et al., (2000) who demonstrated that addition of propolis caused increase of phosphorus level in bones. Probably propolis inclusion in the diet increases absorption of phosphorus from the blood to the bone and thus decreased the level of these elements in the blood.

These results are Confirmed by the discussion of Ang et al., (2009), who demonstrated that propolis has been shown to have anti-tumor and anti-inflammatory properties, Low concentrations of caffic acid phenyl ester(cape) <1microM dose dependently inhibited RANKL-induced osteoclastogenesis in RAW264.7 cell and bone marrow macrophage (BMM) cultures, as well as decreasing the capacity of human osteoclasts to resorb bone. CAPE inhibited both constitutive and RANKL-induced NF-kappaB and NFAT activation, concomitant with delayed IkappaBalpha degradation and inhibition of p65 nuclear translocation. At higher concentrations, CAPE induced apoptosis and caspase 3 activities of RAW264.7 and disrupts the microtubule network in osteoclast like (OCL) cells, which results in the attenuation of osteoclastogenesis and bone resorption, implying that CAPE is a potential treatment for osteolytic bone diseases.

The haemagglutination inhibition of broilers chicks affected by propolis supplementation is listed in Table (4). Propolis supplemented group at 125 and $250 \mathrm{mg} / \mathrm{kg}$ were $(5,3.5)$ higher than the control group and supplemented group of $500 \mathrm{mg} / \mathrm{kg}(3,2.67)$ in the (NDV) antibodies titer, 10 days after vaccination.

A similar results were found by Taheri et al., (2005) who found that, antibody titer against avian Influenze, newcastle disease virus and BD were significantly $(\mathrm{P}<0.05)$ increased with oil extract of propolis supplementation, without any effect on IB.

In addition, Hegazi et al. (2012) reported that, propolis extract treated group was the highest in the (NDV) antibodies titer (4.9, 6.4 and 7.7) when compared with control group (2.7, 2.2 and 1.9) on 14, 21 and 28 days.

Table (4). Effect of dietary propolis supplementation on HI (Mean \pm SE) against NDV of broiler chickens after 10 days of vaccination.

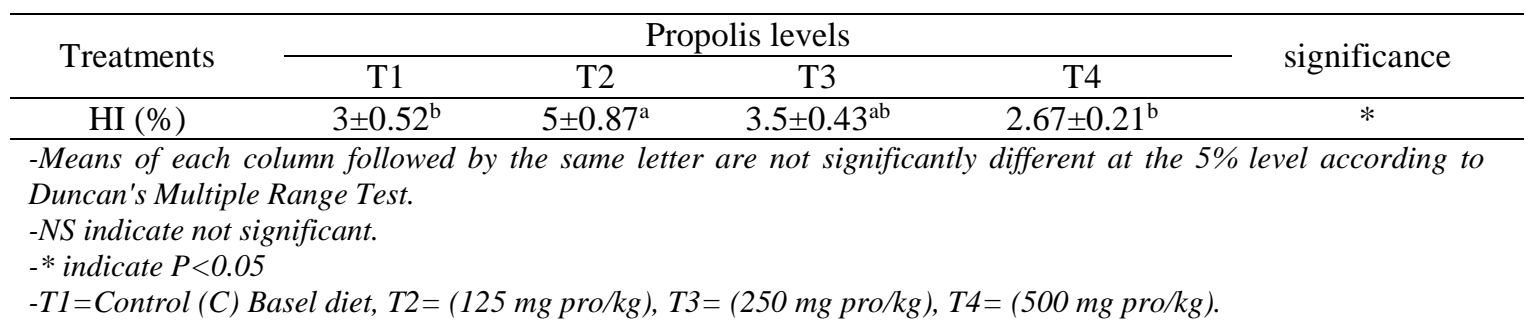

\section{CONCLUSIONS}

In conclusion, this study demonstrated that propolis supplementation may be a good enhancer to the tibia length, tibia percentage of the total body weight, phosphorus and calcium concentrations as well as immunological status against NDV.

\section{REFERENCES}

Ang, E.S.; N.J. Pavlos; Y.L. Chai; M. Qi; T.S. Cheng; J.H. Steer; D.A. Joyce; M.H. Zheng; and J. Xu (2009). Caffeic acid phenethyl ester an active component of honeybee propolis attenuates osteoclastogenesis and bone resorption via the suppression of RANKL-induced NF-KB and NFAT activity. J Cell Physiol., 221: 642-649.

Anon (1990). Laboratory manual for the isolation and identification of avian pathogens. 3rd Ed., A. A. A. P. Arnold corporation Ithace, New York.

Attia, Y.A.; A.M. Al-Hanoun; A.E. Tag El-Din; F. Bovera and E. Shewika (2011b). Effect of bee pollen levels on productive, reproductive and blood traits of NZW rabbits. J. Anim. Phys. Anim. Nutr., 95:294-303.

Attia, Y.A.; H.S. Zeweil; A.A. Alsaffar and A.S. El-Shafy (2011c). Effect of nonantibiotic feed additives as an alternative to flavomycin on broiler chickens production. Arch. Geflügelkd, 75:40-48.

Bankova, V. (2005). Chemical diversity of propolis and the problem of standardization. J. Ethnopharmacol, 100, 114-7.bone marrow cells of mice. Iranian Journal of Cancer Prevention, 2:4. 


\section{Abou-Zeid et al.}

Cook, M.E. (2000). Skeletal deformities and their causes: Introduction. Poult. Sci., 79:982-984.

Danbury, T.C.; C.A. Weeks; J.P. Chambers; A.E. Waterman-Pearson and S.C. Kestin. (2000). Selfselection of the analgesic drug carprofen by lame broiler chickens. Vet. Rec., 146:307-311.

Duncan, D.B. (1955). Multiple range and multiple F tests. Biometric, 11:42.

Fiske, C.H. and Y. Subbarow (1925). The colorimetric determination of phosphorus. J Biol Chem., 66:375-400.

Galal, A.; A.M. Abd El-Motaal; A.M.H. Ahmed and T.G. Zaki (2008). Productive performance and immune response of laying hens as affected by dietary propolis supplementation. Int. J. Poult. Sci., $7: 272-278$.

Haro, A.; I.L. Aliaga; L. Francisco; M. Barrionuevo; M.J.M. Alfe'rez and M.S. Campos (2000). Beneficial effect of pollen and/or propolis on the metabolism of iron, calcium, phosphorus, and magnesium in rats with nutritional ferropenic anemia. J. Agric. Food Chem., 48:5715-5722.

Hegazi, A.E.; M.A. Amr and A. Fyrouz (2012). Egyptian Propolis 9- Its Effect on Chicken Productivity and Immune Response Against Newcastle Disease Vaccine. British Journal of Poultry Sciences, 1(3):25-30.

Horn, P. (2000) Breeding and management aspects of broiler production. Arch Tierz 43 Special Issue, 106-110 [in German].

Ihsan, M.S.; H.A. Balqees and H.Z. Abd-alameer (2013) effect of propolis in diet supplementation on the histopathological changes in some organs and challenge tests against newcastle disease in broiler chicks. Magazin of Al-Kufa University for Biology / VOL.5 / NO.2 Int Beekeep. Congr Summ, 211 7.

Khojasteh, S. and M. Shivazad (2006). The effect of diet propolis supplementation on Ross broiler chicks performance. International Journal of Poultry Science, 5:84-88.

Kleczek, K. Majewska; K. Makowski and Włodzimierz (2012). The effect of diet supplementation with propolis and bee pollen on the physicochemical properties and strength of tibial bones in broiler chickens. Archiv Tierzucht, 55 (2012) 1, 97-103, ISSN 0003-9438.

Leterrier, C. and Y. Nys (1992) Composition, cortical structure and mechanical properties of chicken tibiotarsi: effect of growth rate. Br Poult Sci., 33:925-939.

Nada, K.H.; H.S. Naher and A.H. Al-Charrakh (2011). Iraqi Propolis: The Antimicrobial Activities. http://www.academicjournals.org/JMPR.

NRC (1994). Nutrient Requirements of Poultry, 9th rev. ed. National Academies Press, Washington, DC, USA.

Popiela, P.; E. Roman; A. Dobrzanski; P. Sewerniak; K. Opalinski and S. Korczynski (2012). Effect of propolis and bee pollen supplementation on selected blood parameters of laying hens. In: Book of Abstracts, World's Poult.Sci.J.(Suppl.1) 659. The 24thWorld Poultry Congress August 5-9, Salvador, BA, Brazil.

Sforcin, J.M. (2007). Propolis and the immune system: A review. Journal of Ethnopharmacology, 113:114.

Sullivan, T.W. (1994). Skeletal problems in poultry: Estimated annual cost and description. Poult. Sci., 73:879-882.

Taheri, H.R.; H.R. Rahmani and J. Pourreza (2005). Humoral immunity of broilers is affected by oil extracted propolis (OEP) in the diet. Int. J. Poult. Sci., 4(6):414-417.

Thorp, B.H. (1994). Skeletal disorders in the fowl: A review. Avian Pathol., 23:203-236.

Whiteside, P. and B. Miner (1984). Pye Unicam Atomic Absorption Data Book. Pye Unicam LTD, Cambridge, UK.

Williams, B.; D. Waddington; D.H. Murray and C. Farquharson (2004). Bone strength during growth: influence of growth rate on cortical porosity and mineralization. Calcif Tissue Int., 74:236-245.

Zimnoch, L.; J. Szarek; J. Abczak and A. Konwicki (2000). Effects of feed supplements on morphological pattern of internal organs in broiler chickens. Zesz Nauk PTZ Prz Hod 49, 65-76 (in Polish). 
تاثير إضافة البروبوليس على الحالة المناعية والخواص الفزيائية والكيميائية لعظام الساق فى دجاج اللحم.

عادل السيد أبوزيد1، سعد زغلول الدمراوي1، يحيى عزيز مرعى2 و صلاح محمد القصاص1

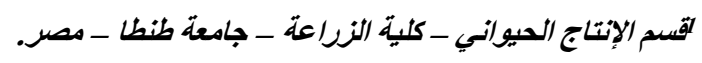

محطة بحوث الاتتاج الحيوانى - مصر.

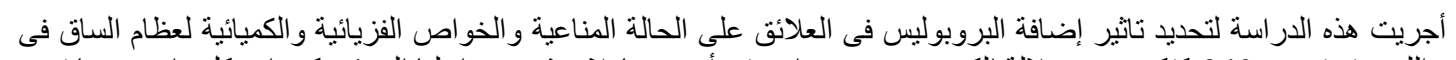

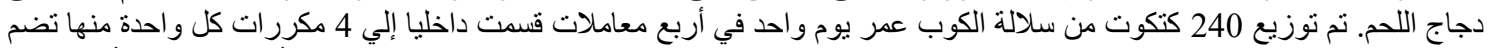

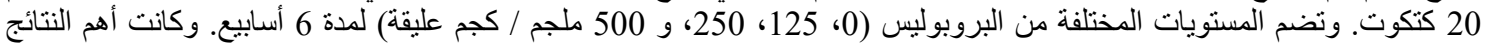

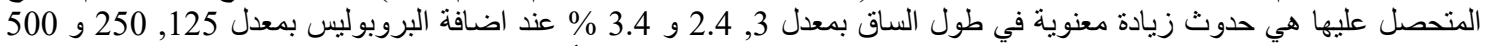

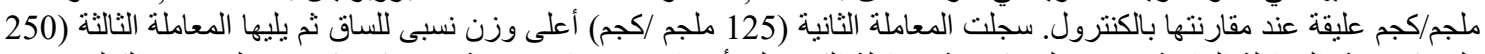

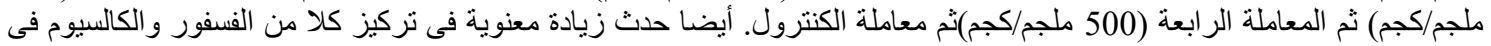

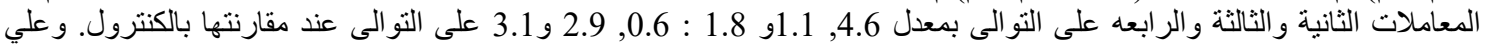

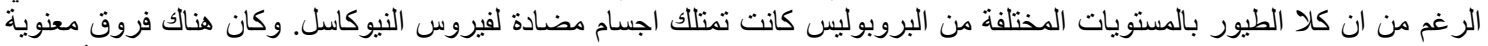

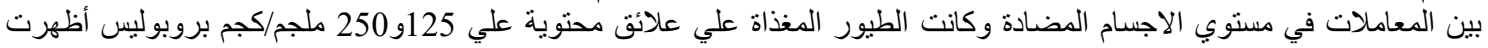

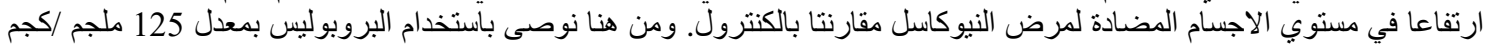

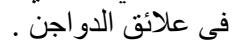

